\title{
Enemies of Israel: Ruth and the Canaanite Woman
}

\author{
Glenna S Jackson ${ }^{1}$ \\ Otterbein College (Westerville, OH, USA) \\ Visiting Professor: University of Pretoria
}

\begin{abstract}
This article elaborates on the author's monograph "Have mercy on me": The story of the Canaanite woman in Matthew 15.21-28 (Sheffield: Sheffield Academic Press, 2002). According to the monograph, Matthew uses the Psalms, the story of Ruth and rabbinic tradition to turn Mark's story of the Syrophoenician woman (7:24-30) into a conversion formula for entrance into the Jewish community. This article employs an intertextuality approach to enhance the theory of proselytism in Matthew's gospel. The Canaanite woman passes threetime rejection, one-time acceptance test that the first-century rabbis delineated from the story of Ruth for converting to Judaism.
\end{abstract}

\section{PREFACE}

The Canaanite Woman and I have become so familiar with one another that there are days when I cannot separate the two; that is, as a New Testament scholar doing historical Jesus research and a fellow of the Jesus Seminar to boot, I am often considered an enemy - of whom, I am not sure - but an enemy nonetheless. The assignment that Professor Andries van Aarde asked me to do for this seminar on "Matthew and Intertextuality", ${ }^{2}$ therefore, has been an intriguing process since I have not engaged in intertextual studies per se. There

\footnotetext{
${ }^{1}$ Prof Dr Glenna S Jackson (Otterbein College, Westerville, $\mathrm{OH}$ ) visited the University of Pretoria in July and October 2000 as guest of Prof Dr Andries G van Aarde (Department of New Testament Studies, Faculty of Theology, University of Pretoria). In July 2003 Prof Jackson and Prof Van Aarde shared the Synoptic Gospels Seminar of the Society of Biblical Literature's (SBL) International Meeting, University of Cambridge (UK), and the Gospel of Matthew Seminar of the Studiorum Novi Testamenti Societas (SNTS), Rheinische Friedrich-Wilhelms-Universität Bonn (Germany). This paper was presented in Bonn on 1 August 2003.

${ }^{2}$ The theme for the cycle of the Gospel of Matthew Seminar of the SNTS for the period 20012004, co-chaired by Prof Dr Andries G van Aarde (University of Pretoria), Prof Dr Jens Herzer (Universität Leipzig), and Dr David Sim (Catholic University of Australia, Melbourne), is "Matthew and Intertextuality".
} 
is no question in my mind that Matthew uses the story of Ruth for the form of the story of the Canaanite woman, but to talk about that relationship using the method of intertextuality and its language is a new experience for me. I ask for your indulgence on this first attempt. ${ }^{3}$

\section{INTRODUCTION}

A rehearsal of my thesis in "Have mercy on me": The story of the Canaanite woman in Matthew 15.21-28 (Jackson 2002) is necessary in order to understand the relationship between the story of Ruth and the story of the Canaanite woman. This paper is dependent in many ways on the outline of that monograph. It is my contention that Matthew composes a model for conversion into that first-century community through the use of the Psalms, the story of the Moabite Ruth and a formula based on the rabbis' interpretation of that story, as well as a modulated and embellished tune from one of Mark's miracle stories. A summary of my argument from a historical-critical standpoint is shown in the following synopsis that shows the alignment of the story of Ruth, Mark's account of the Syrophoenician woman (Mk 7.24-30), and Matthew's account of the Canaanite woman (Mt 15.21-28) (see Jackson 2002:135-136):

\begin{tabular}{|l|l|l|l|}
\hline & Ruth & Mark & Matthew \\
\hline 1. Request: & $\begin{array}{l}\text { But Naomi said to two } \\
\text { daughters-in-law "Go, } \\
\text { return each of you to } \\
\text { her mother's house } \\
\text {.." (1:8a). }\end{array}$ & $\begin{array}{l}\text { And she begged him } \\
\text { to cast the demon out } \\
\text { of her daughter (7:26). }\end{array}$ & $\begin{array}{l}\text { "Have mercy on me, } \\
\text { Lord, Son of David; } \\
\text { my daughter is badly } \\
\text { demonized" (15:22b). }\end{array}$ \\
\hline Rejection: & $\begin{array}{l}\text { And they said to her, } \\
\text { "No, we will return } \\
\text { with you to your } \\
\text { people" (1:10). }\end{array}$ & $\begin{array}{l}\text { But he did not answer } \\
\text { her a word (15:23a). }\end{array}$ \\
\hline 2. Request: & $\begin{array}{l}\text { But Naomi said, "Turn } \\
\text { back, my daughters, } \\
\text { why will you go with } \\
\text { me (1:11a). }\end{array}$ & $\begin{array}{l}\text { And his disciples } \\
\text { came and asked him, } \\
\text { saying, "Send her } \\
\text { away, for she is still } \\
\text { crying along behind } \\
\text { us" (15:23b). }\end{array}$ \\
\hline Rejection: & $\begin{array}{l}\text { "Have I yet sons in my } \\
\text { womb that they may } \\
\text { become your } \\
\text { husbands" (1:11b)? }\end{array}$ & $\begin{array}{l}\text { But he answered, } \\
\text { saying, "I was sent } \\
\text { only to the lost sheep } \\
\text { of the house of Israel" } \\
\text { (15:24). }\end{array}$ \\
\hline
\end{tabular}

\footnotetext{
${ }^{3}$ I must credit one of my mentors, Richard A Edwards, however, for introducing the general concept of narrative criticism to me.
} 


\begin{tabular}{|c|c|c|c|}
\hline 3. Request: & $\begin{array}{l}\text { "Turn back, my } \\
\text { daughters, go your } \\
\text { way" (1:12). }\end{array}$ & & $\begin{array}{l}\text { But she came } \\
\text { worshipping him, } \\
\text { saying, "Lord, help } \\
\text { me" (15:25). }\end{array}$ \\
\hline Rejection: & $\begin{array}{l}\text { Then they lifted up } \\
\text { their voices and wept } \\
\text { again; and Orpah } \\
\text { kissed her mother-in- } \\
\text { law, but Ruth clung to } \\
\text { her (1:14) }\end{array}$ & $\begin{array}{l}\text { And he said to her } \\
\text { "Let the children first } \\
\text { be fed, for it is not } \\
\text { pleasing to God to } \\
\text { Take the childrens } \\
\text { Bread and throw it to } \\
\text { the dogs }(7: 27)\end{array}$ & $\begin{array}{l}\text { But he } \\
\text { answered,saying, "It is } \\
\text { not pleasing to God to } \\
\text { take the children's } \\
\text { bread and throw it to } \\
\text { the dogs" (15:26). }\end{array}$ \\
\hline 4. Request: & $\begin{array}{l}\text { And she said "See } \\
\text { your sister-in-law has } \\
\text { gone back to her } \\
\text { people and to her } \\
\text { gods; return after your } \\
\text { sister-in-law" (1:15). }\end{array}$ & $\begin{array}{l}\text { But she answered } \\
\text { him, "Yes, Lord; yet } \\
\text { even the dogs under } \\
\text { the table eat the } \\
\text { children's crumbs" } \\
(7: 28) .\end{array}$ & $\begin{array}{l}\text { But she said, "Yes, } \\
\text { Lord, yet even the } \\
\text { dogs eat the crumbs } \\
\text { that fall from the table } \\
\text { of their masters" } \\
(15: 27) \text {. }\end{array}$ \\
\hline Response: & $\begin{array}{l}\text { But Ruth said, } \\
\text { "Entreat me not to } \\
\text { leave you or to return } \\
\text { from following you; for } \\
\text { where you go I will go, } \\
\text { and where you lodge I } \\
\text { will lodge; your people } \\
\text { shall be my people, } \\
\text { and your God my God } \\
\text {..." (1:16). }\end{array}$ & $\begin{array}{l}\text { And he said to her } \\
\text { "For this saying you } \\
\text { may go your way; the } \\
\text { demon has left your } \\
\text { daughter". }\end{array}$ & $\begin{array}{l}\text { Then Jesus } \\
\text { answered, saying to } \\
\text { her, "O woman, great } \\
\text { is your faith! Be it } \\
\text { done for you as you } \\
\text { will". }\end{array}$ \\
\hline Resolution: & $\begin{array}{l}\text { And when Naomi saw } \\
\text { that she was } \\
\text { determined to go with } \\
\text { her, se said no more } \\
(1: 18) \text {. }\end{array}$ & $\begin{array}{l}\text { And she went home, } \\
\text { and found the child } \\
\text { lying in bed, and the } \\
\text { demon gone ( } 7: 9-30) \text {. }\end{array}$ & $\begin{array}{l}\text { And her daughter was } \\
\text { healed at that hour } \\
(15.28) \text {. }\end{array}$ \\
\hline
\end{tabular}

According to my argument, the synopsis shows that the woman from Tyre and Sidon in Matthew's story first asks for Jesus' help by telling him that her daughter is demonized, but Jesus ignores her. She persists by crying along behind the group of disciples with Jesus, and this time he answers her with the [so-called] Exclusivity Logion that the evangelist has already used in 10.6, indicating that Jesus is only ministering to those of the Jewish faith and since she is a Canaanite from Tyre and Sidon, she is not one of them. She does not go away, however; she comes back even more humbled, only to be stung more deeply by Jesus' words about dogs. To his retort, she responds with a fourth and final request: "Yes, Lord, yet even the dogs eat the crumbs that fall from the table of their masters" (Mt 15:27). The woman from Tyre and Sidon is commended for her faith and her daughter is healed (Jackson 2002:138). 
According to the rabbis of the first century, the story of Ruth's refusal to leave Naomi and go back to her homeland becomes the formula for one to convert to Judaism; that is, one must go through a four-time request, three-time rejection, and, finally, reception period in order to become one with the community (see Bamberger 1968:40; Neusner 1994:49-50). ${ }^{4}$ Matthew, following the rabbis' lead, does the same by articulating a proselytic formula in the retelling of Mark's Syrophoenician woman in his story of the Canaanite woman. ${ }^{5}$

\section{MATTHEW'S METHOD}

The first question then becomes that of whether the alleged intertextuality between the stories of the Canaanite woman and Ruth is Matthew's direct use of the story of Ruth or that he demonstrates a familiarity with and use of a firstcentury rabbinic formula for proselytism. While this is a part of the "historical Matthew" quest, ${ }^{6}$ for the purposes of this paper I will argue that it was a knowledge and mixture of both the story itself and the subsequent tradition. The second question (but the last will be first) must consider the definition and/or scope of the term "intertextuality".

Dale C. Allison, Jr (2000:ix) suggests that the term intertextuality "refers to all of the potential relationships between texts". He then discusses and defines the three different forms of intertextuality that he uses in his study of Q (Allison 2000:x):

- quotation ("the reproduction of several consecutive words from another text"),

- reference ("directs individuals to a text in their portable mental library, not by quoting from it, but by mentioning it or some episode in it outright"), and

\footnotetext{
${ }^{4}$ My complete argument on Matthew's use of the story of Ruth and its rabbinic formula can be found in Jackson (2002:126-37).

${ }^{5}$ I want to emphasize the fact that I neither historicize the Canaanite woman herself nor the Old Testament stories: "It has yet to be determined what written or oral traditions the evangelist actually had in hand or head. Dependence on the Old Testament text is obvious; whether or not that text was believed to be historical is not an issue. It was the text that counted, and the text that would determine the rules for living in community" (Jackson 2002:21). Interestingly, Funk \& The Jesus Seminar (1998:212-214) color coded the story of the Canaanite woman (and the story of the Syrophoenician woman) gray, but "allowed that it had a pink core [because the story did seem to] reflect a distant memory of an actual event".

${ }^{6}$ For further discussion, see Jackson (2002:21-24, 137-40).
} 
- allusion ("when one text shares enough with another text, even without reproducing several consecutive words from it, to establish the latter as a subtext to which an audience is being implicitly directed'). ${ }^{7}$

Jean K Kim (1999:63) expanding on Mikhail Bakhtin's notion of "dialogicity", uses the term "inter(con)textual", meaning that "someone who writes is not only led by text-immanent considerations but also enters into dialogue with readers' texts and reality". ${ }^{8}$ With those terms and definitions in mind, I will show that, in the case of the story of the Canaanite woman, Matthew "refers", "alludes", "dialogicizes", and "inter(con)textualizes". The Evangelist also "mirrors" and "imitates" 9 the tradition that is rooted in the story; that is, anything but "quotes".

My thesis is that Matthew's methods of 'intertextuality' enabled future Christian interpreters to obscure the historical context of the pericope of the story of the Canaanite woman, thereby losing its original context and meaning. In order to make that argument, I will first give a brief description of Matthew's use of the OT, the Evangelist's specific use of the story of Ruth, a condensed history of interpretation for the story of the Canaanite woman, and a conclusion.

\section{MATTHEW'S USE OF THE OLD TESTAMENT}

The importance of Matthew's use and interpretation of Old Testament passages has been discussed for decades (e g, Von Dobschütz 1928:338-348; Stendahl

\footnotetext{
${ }^{7}$ Other scholars use the phrase 'narrative echoes'; e g, Patrick E. Spencer, 'Narrative Echoes in John 21: Intertextual Interpretation and Intratextual Connection', JSNT 75 (1999), 49-68.

${ }^{8}$ According to Kim, the term "intertextuality" was first introduced by Julia Kristeva, who was influenced by Mikhail Bakhtin.

${ }^{9}$ While it is tempting to test the relationship between the stories of Ruth and the Canaanite woman for Dennis R MacDonald's six criteria for "mimesis" (accessibility, analogy, density, order, distinctive traits, and interpretability), I think that Matthew's pericope in and of itself is not long enough (see MacDonald 2001:2-3). What might be interesting is to examine the entire gospel of Matthew in the light of a theme of proselytism and see if it 'mimics' any other ancient stories or manuals on conversion.
} 
1968; Gundry 1967). J Andrew Overman (1990:78) summarizes the connection: ${ }^{10}$

Jesus and the life of the Matthean community are in continuity with the traditions and promises of Israel's history. Indeed, as a result of this distinctive use of Scripture by Matthew, Jesus - and through him the Matthean community - is depicted as the fulfillment of that very history and tradition. This constitutes both a defense of Matthew's community and a challenge to the opposition.

Matthew incorporates many Old Testament texts in the story of the Canaanite woman, but there are two major, and obvious, times that are relevant to this study. ${ }^{11}$ In fact, both of these references occur at the outset of the story and set up the listener or reader for something extraordinary to happen.

Matthew's use of the geographical location "Tyre and Sidon" is the first major use of the Old Testament in the pericope of the Canaanite woman. Matthew "refers" to the cities several times in the gospel, "alludes" to their reputation, and depends on the listeners' and readers' memory banks to "dialogicize" or "inter(con)textualize". In the case of these particular cities, one's "portable mental library" will conjure up two images (Jackson 2002:35). On the positive side, the inhabitants of Tyre and Sidon are an intelligent, skilled people who give generously to the kings of Israel, and are used by God to offer help in time of need. On the negative side, they are often described as enemies of Israel, primarily because of their foreign gods, and consequently serve as the victims of God's wrath on many occasions.

Thus, while Matthew "alludes" to Tyre's and Sidon's four functions in the Old Testament as examples of negative ethical behavior, as outsiders to the

\footnotetext{
${ }^{10}$ As already mentioned, the issue of the 'historical Matthew' is also pertinent if one is to understand the context from which and the view to which the author writes. Contemporary scholars, e g, Ulrich Luz (1995:11-21) and David C Sim (1998), review the literature and point out the problems of definitions such as "Gentile Christian writing for a Gentile-Christian community", "Jewish Christian", "member of a mixed community", or "sectarian Jew". In regard to this study then, the "historical Jackson" must also be stated so that biases are part of the conversation: "I fall on the side of Matthew being a Jew whose community abided by the Torah, whether to the last 'tittle and jot' remains to be determined; I am reluctant to call Matthew's community a 'church'" (Jackson 2002:24).

${ }^{11}$ See Jackson (2002:111-126) for Matthew's inclusion (and allusions) to the Psalms and other Old Testament texts.
} 
Jewish faith, as friends of Israel, and as participants in the same salvation as the Jews (Jackson 2002:36), ${ }^{12}$ it is obvious that the gospel writer also depends upon first-century readers and listeners to be able to contextualize those functions in this new story about a Canaanite woman because he never spells out the references. Matthew's borrowing of the setting of Tyre (and Sidon) ${ }^{13}$ from Mark enables the writer to immediately set up what may be a solution for the debate between Jews and Gentiles in the community.

Matthew's second use of the Old Testament in this pericope centers on the woman's designation as a Canaanite. Not only does Matthew add "and Sidon" to Mark's geographical setting, but also changes the description of "the woman was a Greek, a Syrophoenician by birth" (Mk 7.26) to "a Canaanite woman" (Mt. 15.22). Again, Matthew counts on the constituents of the community to "inter(con)textualize" the meaning without explaining it. That is, Canaanites, as an historical group of people, did not exist in the first century. ${ }^{14}$ However, the term was recognizable as a vicious epithet toward anybody who was considered contemptible to the Jews. ${ }^{15}$ Neils Peter Lemche (1998:11), suggests that the term "Canaanite" never did refer to an historical people; that is, the term is a

literary device created in order to make a distinction between the heroes of the narrative, the biblical Israelites, and the villains, the Canaanites. They came to symbolize the non-Israelite population living in Palestine at any moment of Israel's history, whether understood to be the history of biblical Israel or of postexilic Judaism. In this way "Canaanite" might in fact simply mean the non-Jewish population of the land of Israel, irrespective of the time and circumstances in which the term appears.

Regardless of their historicity or fictiveness, Matthew uses the literary "context" of the "Canaanites" in the first-century story setting because listeners or readers

\footnotetext{
${ }^{12}$ See the entire first chapter "Tyre and Sidon: A paradigmatic setting" in Jackson (2002:27-59).

${ }^{13}$ See Jackson (2002:43-45) for a discussion of Mark's setting of Tyre and Matthew's setting of Tyre and Sidon.

${ }^{14}$ I agree with Alice Dermience (1982:29; see also John P Meier (1991-2001:2.675). David Novak (1983:60) argues the same archaism of the term "Canaanite" in the Talmud.

${ }^{15}$ See others who make this claim earlier; e g, Roy A Harrisville (1966:280-281); Marla J Selvidge (1987:79; see also the entire second chapter of Jackson (2002:60-100), "The Canaanites in Matthew's gospel).
} 
can "dialogicize" with the concept. And so, the extraordinary sense of surprise that the audience appropriates from this story's beginning is that they are about to hear heresy. As a matter of fact, this will not be the first time that they have heard shocking stories about enemy women in Matthew's gospel story about a Jewish messiah.

\section{MATTHEW'S USE OF THE STORY OF RUTH}

The one and only time that Ruth is mentioned (or directly referenced) in the Gospel of Matthew is in the genealogy with its unique inclusion of four women. ${ }^{16}$ While all four women are enemies of Israel (Canaanites Tamar and Rahab, Moabite Ruth, and Hittite Bathsheba) ${ }^{17}$ and get pregnant through unorthodox ways (Tamar poses as a prostitute for Judah's pleasure, Rahab is a harlot, Ruth seduces Boaz, and Bathsheba is seduced [or raped] by King David), Ruth is probably the most important one on the list because she gives birth to Obed. Ruth and Boaz are thus the ancestral grandparents of King David from whose house Jesus is born.

One of the debates about the story of Ruth continues to be whether or not it was written to settle the issue of "universalism versus exclusivism". The rabbis were convinced that this issue was the major theme. In fact, they constructed a model of conversion from her story. The paradigm for proselytism is based on Ruth's refusal to leave her mother-in-law Naomi, even though all of the men in the family are dead and Ruth, theoretically, has no future if she travels with Naomi back to Bethlehem. But Ruth is insistent and turns down Naomi's request three different times, finally wears her down with the fourth, and they travel together to Naomi's homeland.

As can be seen from the synopsis of Ruth, Mark, and Matthew (above), Matthew "mirrors", rather than "quotes", the tradition that is rooted in the story of Ruth. That is, Naomi makes the requests and Ruth the proselyte turns her down. Conversely and mirror-like, the Canaanite woman-proselyte makes the requests while Jesus turns her down.

\footnotetext{
${ }^{16}$ For my argument that the inclusion of the four women in the genealogy is for the purpose of Matthew's articulation of salvation for the Gentiles through Israel (i e, not to the Gentiles directly), see Jackson (2000:935-948).

${ }^{17}$ For a summary of the literature and arguments on this topic, see Jackson (2002:86-99).
} 
It is also noteworthy that Naomi instructs Orpah and Ruth to return to Moab, where they have both kinspeople and gods; one's "portable mental library" should conjure up the fact that a number of Old Testament writers depict God's anger with the Israelites' worship of the gods of Moab as well as their worship of the gods of Sidon, that is Canaan (Jud 10.6; Ps 83.7). Therefore, Matthew connects memories and knowledge of Canaan, Tyre and Sidon, Moab and Ruth. Also note the final mirror image of the synopsis: "Naomi is silent after the fourth request while Jesus is silent after the first request; silence on Naomi's part indicates acceptance while silence on Jesus' part indicates rejection" (Jackson 2002:129 n 80).

Matthew also "imitates" the story of Ruth. According to the rabbis, Ruth's words follow Naomi's admonishment that if Ruth is so eager to share Israel's sufferings, she must be tireless in the fulfillment of commandments and the doing of good deeds in this world. Ruth's response is a commitment to a covenant; if she is allowed to follow Naomi, she will be faithful to Naomi's God. Since Moabites and Canaanites are both designated enemies of Israel, Matthew's Canaanite woman is an imitation of the story of Ruth: if the Canaanite woman is allowed to follow Jesus (i e, win an argument, according to the story, just like Ruth did), she will be allowed to gain entry into the community. ${ }^{18}$

Matthew's audience had an advantage over us; that is, they knew the tradition that the story of Ruth spawned within first-century Judaism: the reading in Dt 23.3 states that Moabites (and Ammonites) are excluded from converting to Judaism. However, the rabbis had to make an exception for Ruth because, after all, she saved Israel by marrying Boaz and giving birth to Obed, thus making her the great-grandmother of King David. Therefore, the Talmud states, "An Ammonite, but not an Ammonitess; a Moabite, but not a Moabitess" (b Yeb 76b; see also b Yeb 69a; b Ket 7b; b Qid 75a). According to Michael S Moore (1998:215-216), the explanation is as follows:

\footnotetext{
${ }^{18}$ It is also tempting to test out the possibility that the story of the Canaanite woman is to Christianity as the story of Ruth is to Judaism; that is, the Moabite Ruth saves Israel by giving birth and the Canaanite woman saves the Jewish sect of Christianity by opening Jesus' mind to the gentiles. However, I think that goes against better historical judgment, as well as my original thesis!
} 
(1) Since the biblical text gives a specific reason for the prohibition of Moabites and Ammonites ["because they did not meet you on the way with food and water"], and (2) since respectable women would not walk on public highways in ancient times, one must conclude (3) that no Ammonite or Moabite woman can fairly be held responsible for this crime, and this means (4) that Ammonite and Moabite women cannot be prohibited from attending Yhwh's assembly. Therefore, (5) Ruth is a legitimate ancestor of David.

In fact, according to Jacob Neusner (1989:4.146), it was on account of the blessings of the foreign women that the line of David was not wholly exterminated. Neusner (1993:82) argues that conversion is discouraged because it is a difficult undertaking:

Because the Judaism of the dual Torah discourages conversion, lest becoming part of holy Israel prove cheap and trivial, Naomi's task is to tell Ruth what is involved in accepting the yoke of the Torah. The Torah imposes heavy responsibilities, separates Israel from Gentiles, and sanctifies life; all of this takes work, commitment, and a constant play of conscience. It is Naomi's task to tell Ruth that what she imagines to do is difficult.

And the specific message of proselytism in Ruth, according to Neusner (1994:4950), includes:

1) The admission of the outsider depends upon the rules of the Torah ... Those who know the rules are able to apply them accurately and mercifully.

2) The proselyte is accepted because the Torah makes it possible to do so, and the condition of acceptance is complete and total submission to the Torah. Boaz taught Ruth the rules of the Torah, and she obeyed them carefully.

3) Those proselytes who are accepted are respected by God and are completely equal to all other Israelites ....

4) What the proselyte therefore accomplishes is to take shelter under the wings of God's presence, and the proselyte who does so stands in the royal line of David, Solomon, and the Messiah ... The point is made that Ruth the Moabitess, perceived by the ignorant as an outsider, enjoyed complete equality with all other Israelites. 
Bamberger (1968:15; see also Moore 1997:1.330) (and others) also weighs in on the subject:

[The book of Ruth] shows that a foreign-born woman can assume and fulfill properly the religious obligations which entrance into the Jewish group demands. Here also the national and religious elements are combined:"Thy people shall be my people and thy God my God." Here also we meet for the first time a phrase which, in slightly modified form, becomes almost a technical term at a later date for conversion: "to take refuge beneath the wings of the Lord" (Ruth 2.12).

In light of the specific equality of proselytes, as stated above, one cannot help but wonder if the story of the Canaanite woman not only conjured up in the memory banks of Matthew's community a time of Canaanites and other enemies of Israel, but also a time when women were equal in status and role. Perhaps the story of the Canaanite woman had that purpose as well. ${ }^{19}$

\section{HISTORY OF INTERPRETATION}

Viewing Matthew's construction of the story of the Canaanite woman from a specifically intertextual frame of mind makes the history of interpretation all the more significant. A modern understanding of the story is that, among the majority of scholars, in a historicizing manner Jesus now has open eyes for the Gentiles and not just "the lost sheep of the house of Israel". ${ }^{20}$

Early interpretations of the story of the Canaanite woman, however, portray her as a proselyte. The author of Pseudo-Clementine, for example, assigns the name of "Justa" to the woman and describes her as a proselyte. Hilary (fourth century $\mathrm{CE}$ ) also presents her as a proselyte who intercedes on behalf of her pagan child. According to Ulrich Luz (1994:27), this was the dominant interpretation from the fourth until the eighteenth century. Even Augustine understood conversion as a miraculous healing (see Frisch 1983:4145, in Horsley \& Llewelyn 1981-98:VIII:173).

\footnotetext{
${ }^{19}$ For feminist readings on the book of Ruth, see, for example, Judith A Kates and Gail Twersky Reimer (1994) and Phyllis Trible (1997:33-42).

${ }^{20}$ For further discussion, see "The history of research" and notes in Jackson (2002:2-10). Benjamin W Bacon (1930:II.219) does describe the Canaanite woman as a "humble, believing proselyte". Anthony J Saldarini (1994:73-74) and Elisabeth Schüssler Fiorenza (1992:100) also acknowledge the proselytic overtones of the story.
} 


\section{CONCLUSION}

There is a sense of bitter irony, then, in the use of intertextual devices in the story of the Canaanite woman. That is, Matthew is successful with this story because the first-century audience knows the story of Ruth and, therefore, can bring its knowledge of her role as proselyte to the new story of the Canaanite woman as well as its understanding of it in a Jewish context. ${ }^{21}$ It is not an historical story about Jesus having his eyes opened up to the gentile world through a clever woman's argument; it is, rather, a Matthean story about how one becomes a member of that particular Jewish community. It appears that even of those commentators in the fourth through eighteenth centuries who kept the image of proselyte in mind when they viewed the story of the Canaanite woman, she was a proselyte into Christianity, not Judaism. As to whether that interpretation was done on purpose or that Matthew's mirror images, allusions, and imitations were culturally lost as the years went by, we may never know. My fear is that Matthew's intertextual devices that would have been obvious to his first-century audience made it easy for later interpreters and theologians to not only obfuscate the original context and meaning, but to spin a Jewish story into a Christian one.

\section{Works consulted}

Allison, D C 2000. The intertextual Jesus: Scripture in Q. Harrisburg, PA: Trinity Press International.

Bacon, B W 1930. Studies in Matthew. 2 vols. New York: Holt, Rinehart \& Winston.

Bamberger, B 1968. Proselytism in the Talmudic period. New York: Ktav.

Dermience, A 1982. La péricope de la Cananéenne (Mt 15, 21-28): Rédaction et théologie. ETL 58, 25-49.

Frisch, P 1983. Über die lydisch-phrygischen Sühneinschriften and die "Confessiones" des Augustinus. EA 2, 41-45.

Funk, R W \& The Jesus Seminar 1998. The Acts of Jesus: The search for the authentic deeds of Jesus. San Francisco, CA: HarperSanFrancisco.

Gundry, R H 1967. The use of the Old Testament in St Matthew's Gospel. Leiden: Brill. (NovTSup 18.)

\footnotetext{
${ }^{21}$ This reminds me of a constant argument we had in our family on many Sunday mornings while our four children were growing up. Our son Thad maintained that he did not believe anything he heard anyway in worship or Sunday school, so why did he have to go? My answer was always, "I don't care what you believe, but you do have to know the story." And I won - he knows the story.
} 
Harrisville, R A 1966. The woman of Canaan: A chapter in the history of exegesis. Interpretation 20, 274-287.

Horsley, G H R \& Llewelyn, S R (eds) 1981-98. New documents illustrating early Christianity. 8 vols. The Ancient History Documentary Research Centre, New South Wales, Australia: Macquarie Unversity.

Jackson, G S 2000. Are the "nations" present in Matthew? HTS 56, 935-48.

Jackson, G S 2002. "Have mercy on me": The story of the Canaanite woman in Matthew 15.21-28. Sheffield: Sheffield Academic Press. (JSNT 228; CIS 10.)

Kates, J A \& Reimer, G T (eds) 1994. Reading Ruth: Contemporary women reclaim a sacred story. New York: Ballantine Books.

Kim, J K 1999. "Uncovering her wickedness": An inter(con)textual reading of Revelation 17 from a postcolonial feminist perspective. JSNT 73, 61-81.

Lemche, N P 1998. The Israelites in history and tradition. Louisville, KT: Westminster John Knox.

Luz, U 1994. Matthew in history: Interpretation, influence, and effects. Minneapolis, MN: Fortress.

Schüssler-Fiorenza, E 1992. But she said: Feminist practices of biblical interpretation. Boston, MA: Beacon Press.

Luz, U 1995. The theology of the Gospel of Matthew. Cambridge: Cambridge University Press.

MacDonald, D R (ed) 2001. Mimesis and intertextuality in antiquity and Christianity. Harrisburg, PA: Trinity Press International. (Studies in Antiquity and Christianity.)

Meier, J P 1991-2001. A marginal Jew: Rethinking the historical Jesus. 3 vols. New York: Doubleday. (ABRL.)

Moore, G F 1997. Judaism in the First Centuries of the Christian Era: The Age of the Tannaim. 3 vols. Peabody, MA: Hendrickson.

Moore, M S 1998. Ruth the Moabite and the blessing of foreigners. CBQ 60, 203-217.

Neusner, J 1989. The Midrash compilations of the sixth and seventh centuries: An introduction to the rhetorical, logical, and topical program: Ruth Rabbah. 4 vols. Atlanta: Scholars Press. (BJS 189.)

Neusner, J 1993. The mother of the Messiah in Judaism: The book of Ruth. Valley Forge, PA: Trinity Press International.

Neusner, J N 1994. The Judaism behind the texts: The generative premises of Rabbinic literature. Atlanta, GA: Scholars Press. (SFSHJ 4.)

Novak, D 1983. The Image of the non-Jew in Judaism: An historical and constructive study of the Noahide laws. New York: Edwin Mellen Press. (Toronto Studies in Theology 14.) 
Overman, J A 1990. Matthew's gospel and formative Judaism: The social world of the Matthean community. Minneapolis, MN: Fortress.

Saldarini, A J 1994. Matthew's Christian-Jewish community. Chicago: University of Chicago Press.

Selvidge, M J 1987. Daughters of Jerusalem. Kitchener, Ontario: Herald Press. Spencer P E 1999. Narrative echoes in John 21: Intertextual interpretation and intratextual connection. JSNT 75, 49-68.

Stendahl, K 1968. The school of St Matthew and its use of the Old Testament. Philadelphia, PA: Fortress.

Sim, D C 1998. The Gospel of Matthew and Christian Judaism: The history and social setting of the Matthean community. Edinburgh: T \& T Clark. (Studies of the New Testament and Its World.)

Trible, P 1997. Ruth: A text in therapy. USQR 51, 33-42.

Von Dobschütz E 1928. Matthew as rabbi and catechist. ZNW 27 (1928), 338-348. Reprinted in Stanton, G (ed), 1995. The interpretation of Matthew, 19-29. $2^{\text {nd }}$ rev edition. Edinburgh: T \& T Clark. (Studies in New Testament Interpretation.) 